\title{
Spatial and Time Balancing Act: Coastal Geomorphology in View of Integrated Coastal Zone Management (ICZM)
}

\author{
Gülizar Özyurt and Ayşen Ergin \\ Middle East Technical University, \\ Civil Engineering Department, \\ Ocean Engineering Research Centre, \\ Turkey
}

\section{Introduction}

Many coastal processes depend on the geomorphology of the coastal area. Although some areas are naturally prone to high risk, anthropogenic actions further alter their geomorphology, rapidly increasing the risk to coastal areas of disasters by disturbing the spatial and time balance of natural processes. It is a given fact that coastal zones are important social and profitable regions with high population densities. Thus, the management of these areas is critical but complex, calling for interdisciplinary approaches. Nevertheless, international and national agencies urge the application of integrated coastal zone management (ICZM) as the most efficient action for sustainable development in the face of diverse problems, such as climate change (IPCC, 2007). Restoring the balance of coastal landforms is one of the major aims of the ICZM process and the explanation of the geomorphological changes that occur on the coast is becoming increasingly important in order to manage coastal resources in a sustainable way (Woodroffe, 2002). While geomorphologic dynamics of coastal areas influence the character of society, the actions of society change the geomorphology at the same time. This is an iterative mechanism that has gained appreciation over the past century. Initially thought of as stand-alone impacts of human intervention on the shorelines, these impacts appeared as connected mechanisms through the dynamics of nature. In the end, they became a threat to human activity at many locations around the world. Additionally, time lag between human intervention and geomorphologic changes underlines the complexity of the management of coastal areas and the importance of scale as a concept for both ICZM and geomorphologic studies (Rotmans and Rothman, 2003).

The determination of spatial and temporal scales is necessary at the start of any research for the well-defined discussion of the results. Although both scales control the level of detail and accuracy of the research, the impact of scale selection on integrated assessments is a well-known but understudied challenge (Rotmans and Rothman, 2003) with the use of different scales having a significant impact on the results, such as leaving important interconnected elements of the system out of the research area (for example, not including 
tributaries or a river basin for a study of coastal erosion). Accordingly, local variability might be missed both in time and in space. The extent of the research area (whether it is a sand grain, a cliff, a coastal town or a region) is determined by a spatial scale using two axes: planform (also called 'long-shore') or profile ('cross-shore') (Woodroffe, 2002). A range of geomorphologic processes and human activities exist on both axes, influencing ICZM plans. The temporal scale is another multilayer factor that is important for the preparation of ICZM plans. Overall, geomorphologic scales exist across a wide range, from seconds to hundreds of years (Davies, 1993). On one side, human activities on coastal areas take a longer time to impact shorelines. First of all, most actions take a couple of years to carry out (for example, dams along river basins causing coastal erosion). Next, human use is expected to continue for 50 to 100 years (maybe more). This range of the temporal scale is also defined as the engineering timescale (French \& Burningham, 2009). On the other hand, ICZM requires a long-term planning perspective, considering short-term benefits and solutions for urgent problems as well as integrating future risks, such as climate change. Although ICZM started as a form of shoreline management and flood risk planning, it evolved into a management concept, covering social, economic and ecological assets and including a diverse range of problems from natural disasters to man-made events - such as oil spillage - being generally accepted within coastal management literature (examples given in McFadden et al., 2007 such as Bower \& Turner, 1997; Sorensen, 1997; European Commission, 1999; Kay \& Alder, 1999; de Groot \& Orford, 2000). Thus, different spatial and time scales exist within an ICZM plan (McFadden et al, 2007) and the geomorphology of coastal areas is one of the important parameters that define these scales.

\section{Coastal geomorphology and ICZM}

The coast is easily defined as one of the most diverse and dynamic environments found anywhere on earth. Many factors (geologic, physical, biological and anthropomorphic) are responsible for shaping the coast and carrying on its dynamic characteristics. Geological events created the sediment that formed the foundation of the modern coastal zone. Over time, various physical processes have acted on this pre-existing geology, eroding, shaping and modifying the landscape. These mechanisms are influenced by tectonics, climate, ecology and human actions. At the same time, many of these drivers can be affected by the evolution of the Earth's surface. Geomorphology is the science that focuses on the quantitative analysis of these drivers and these physical processes that shape the Earth's surface (Sanders \& Clark, 2010). The nature of these processes depends strongly on the landscape or landform under investigation and the time scales and length scales of interest. The primary driving forces that cause change in most landforms include wind, waves, chemical dissolution, groundwater movement, surface water flow, glacial action, tectonics and volcanism.

Coastal geomorphology deals with the shaping of coastal features (landforms), the processes at work on them and the changes taking place (Bird, 2008). Understanding changes at the coast can require an examination of processes well outside the coastal zone, focusing on the interactions of coastal-zone features and hydrologic, meteorological and fluvial forces by means of sediment transport. Fluid dynamics produce sediment transport, causing geomorphic change to a continuous extent of temporal and spatial scales. On the other hand, the change of geomorphic features alters the boundary conditions for fluid dynamics. In 
turn, it produces further variations in sediment-transport patterns which again cause changes in geomorphic features. These processes happen over a wide range of spatial and temporal scales (Fig. 1). For example, interaction with the near shore profile changes the properties of waves (generated by offshore storms) when entering the coastal zone (Woodroffe, 2002). The resulting wave and flow characteristics control the cross-shore and long-shore variations. The characteristics of the bottom slope and the variations of waves and tides dominate the dynamics of sediment fluxes, causing changes such as erosion and accretion. On the other hand, small-scale processes control the turbulent dissipation of breaking waves, the bottom boundary layer and the bed form mechanisms that shape the local sediment flux (US Army Corps of Engineers, 2003).

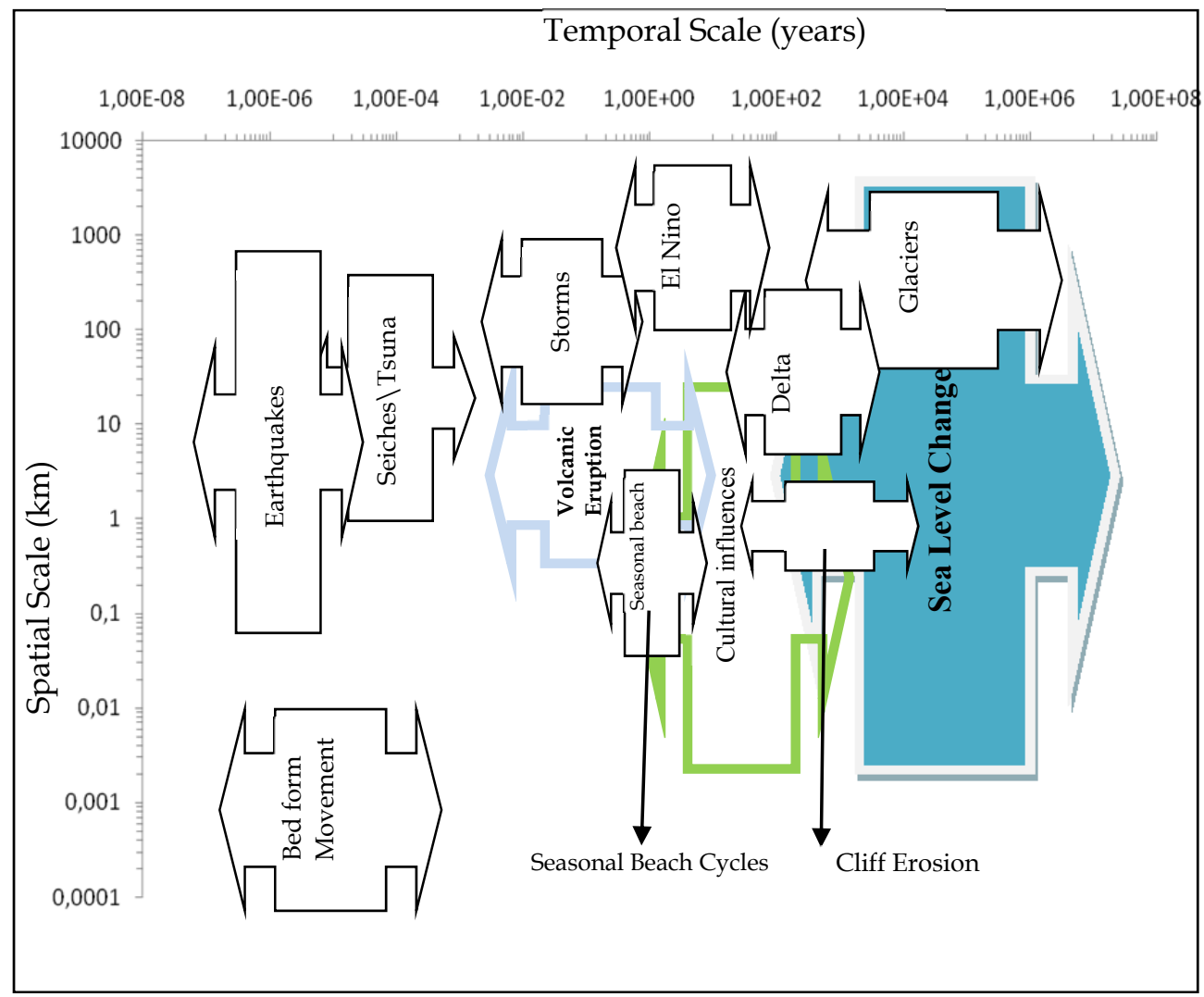

Fig. 1. Temporal and spatial scales of geomorphologic and coastal processes.

The rate of the response of geomorphic features to coastal processes depends on the scale, with larger features taking relatively longer to change. For example, under large waves significant changes in small-scale bed forms can occur within a single wave cycle, but changes in large-scale bed forms are established some time after the occurrence of the main driving force. Winds, waves, tides, storms and stream discharge are important driving forces in the coastal zone (Woodroffe, 2002). 
In addition to the two main axes (long-shore and cross-shore), the coastal zone can be classified as micro-, meso- or macro-cell so as to define the spatial scale (Schwartz, 2005). Micro-cells include smaller geomorphic features such as ripples and small beach-face features which change over the period of a day or even hours. Meso-cells include geomorphic features such as beach profiles which change over a year or else months. Macrocells extend for kilometres and include large coastal geomorphic features.

It is this macro-scale that presents one of the grand challenges of coastal geomorphology. Relating the prediction of morphodynamic behaviour at a meso-scale is of particular relevance for the understanding and management of coastal responses to environmental change. However, the study of coastal processes has traditionally been restricted to small and intermediate scales (Thornton et al. 2000 cited in French \& Burningham, 2009), making it but one of several influences on the coastal zone (Fig. 2). For decadal-scale studies, coastal researchers use the 'one line' shoreline change model, which remains popular, especially for the prediction of the wider impact of engineering schemes. However, system linkages are rarely linear and numerical morphodynamic models are required to understand the quantitative response of the coastline to environmental forcing. Thus, meso-scale morphodynamic modelling is likely to be one of the most active research fronts in coastal geomorphology for the near future (French \& Burningham, 2009). Unfortunately, at present the application of a single model cannot address most large-scale problems. Multiple models are typically required to achieve a reasonable qualitative and quantitative prediction of morphological changes (Hommes et al. 2007 cited in French \& Burningham, 2009).

While many mechanisms such as human intervention, the climate and the sea level affect the coastal geomorphology in addition to coastal processes (Fig. 2), coastal geomorphology has a significant influence on those mechanisms as well. Depending on the characteristics of certain coastal landforms, most of the human activities that take place in coastal areas relate to tourism, agriculture and transportation (Woodroffe, 2002). Moreover, many structures are built on shorelines so as to ensure the sustainability of these activities. This cycle of affecting one another is what makes the design and implementation of ICZM complicated. Different uses of the same coastal resources might generate serious problems, especially under the threat of global forces such as climate change (IPCC, 2007). Also, the application of geomorphologic methods to predict the status of landforms usually covers small spatial scales and short term temporal changes as compared with scales of climate change and ICZM. ICZM practice requires longer time scales and larger spatial scales, and it relies on prediction of shoreline movements and landforms. There are various tools $\backslash$ models presented in the literature for different landforms and mechanisms, and it is the main challenge for ICZM practitioners to integrate and discuss the results of different models in order to come up with one plan for the coastal domain. That is why integrated assessment models have recently gained importance in coastal zone management research (McFadden et al, 2007). The threat of climate change and the impact related to sea level change has seen focus on longer term predictions as well. However, longer term predictions come with higher uncertainties. Thus, at the moment coastal policymakers need to select appropriate scales and tools so as to ensure the sustainable development of coastal areas, taking account of the different spatial and temporal scales of many mechanisms, each possessing different levels of uncertainties (IPCC, 2007). On the other hand, international agencies continue to call for integrated assessments of all disciplines - not just coastal processes - while much of the research focuses solely on one aspect of the question. 


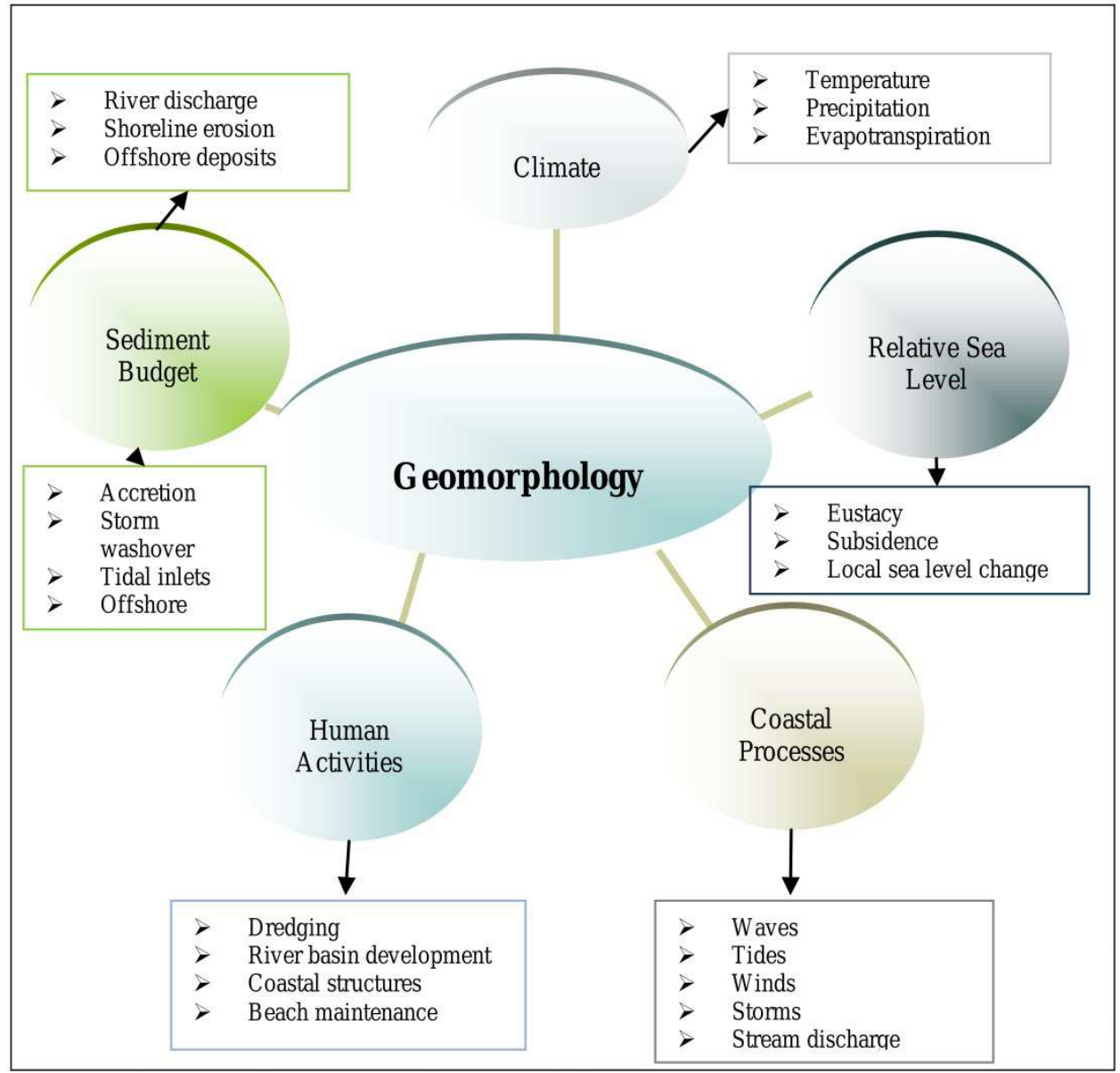

Fig. 2. Mechanisms affecting coastal geomorphology.

Vulnerability assessments are one of the tools used by coastal researchers to highlight the problem areas $\backslash$ sectors $\backslash$ processes that need management, both at the present and in the future. There are different vulnerability assessment methods which use only numerical modelling or highly qualitative procedures answering a range of questions from different perspectives (IPCC, 2007). Despite the use of computers, geographical information systems, remote sensing technologies, data management and support systems and developed methodologies, there remain many unknowns, uncertainties and challenges to overcome, both for the research community and for practitioners (IPCC, 2007; Klein and Nicholls, 1999). Most coastal areas lack continuous data collection or monitoring systems, which hinders the implementation of many of the available numerical models. For these regions, relying on the local experience of practitioners as well as historical events making up the concept of expert opinion is what the decision-making process generally corresponds to. Expert opinion - although a valuable tool - is subjective in nature when decision-making is considered. Keeping in mind that the wrong decision-making process could cause 
irreversible consequences for coastal areas, tools that could integrate expert opinion in an objective way with the available data and generic models and tools would mark an important step for the management of coastal areas where the monitoring and assessment of the implementation of developed plans could be scientifically verified. One such vulnerability assessment model was developed by Ozyurt (2007) and then upgraded in 2010 as a tool using fuzzy expert systems to integrate physical characteristics with human activities on both cross-shore and long-shore spatial extents for coastal areas (Ozyurt, 2010).

\section{Coastal geomorphology and the Fuzzy Coastal Vulnerability Assessment Model (FCVAM)}

The Fuzzy Coastal Vulnerability Assessment Model uses a total of 20 parameters (13 physical and 7 relating to human activity) to define such processes as coastal erosion, inundation, flooding due to storm surges and saltwater intrusion to freshwater resources (groundwater and rivers) along coastal areas. The Fuzzy Coastal Vulnerability Assessment Model (FCVAM) evaluates different areas through aggregated coastal vulnerability. At the same time, a region can be assessed for its vulnerability to different impacts. In addition, the vulnerability of governing physical $\backslash$ anthropogenic parameters is evaluated for individual impacts. The model uses an analytical hierarchy process to integrate stakeholder opinion with the decision-making process; the fuzzy expert system to combine expert opinion, the available data and generic coastal engineering knowledge and geographical information systems in order to present the results of the assessment of the vulnerability of coastal areas, integrating the impacts of sea level rise. The integration of important human activities - such as river basin management, land use and coastal engineering structures - with physical processes - such as waves, tides and sea level rise - on a process level is also achieved through the fuzzy coastal vulnerability model. Several spatial scales can be used for the implementation of the model and each spatial scale aims to be used for distinct purposes, directly related to coastal management practice. The implementation of the model to a coastal region would serve the purpose of a national vulnerability assessment determining "hotspots". Site-specific implementation, on the other hand, serves the purpose of developing a framework for adaptation planning.

The fuzzy coastal vulnerability model uses the main components of fuzzy expert systems, such as parameter membership functions, rule bases and fuzzy arithmetic, as well as clustering and data analysis tools such as the fuzzy c-means algorithm. The database used to develop the parameter membership functions is combination and integration of data covering European coastlines. Rule bases are developed by analysing the numerical models used to define coastal processes and the literature on climate change. The MATLAB Fuzzy Logic Toolbox is used to construct the fuzzy expert system, which is based on a modular structure enabling the future extension of the capability of the present model. Fuzzy arithmetic is also utilised in addition to a rule base expert system in order to determine the coastal vulnerability index. The details on the methodology of the fuzzy coastal vulnerability assessment model are presented in Ozyurt (2010). On the other hand, the focus of this chapter looks to discuss the role of geomorphology within the fuzzy coastal vulnerability model as well as the integration of spatial and temporal scales within the model in view of the different scales of geomorphology and ICZM through examples of application of the model. 
Of the impacts assessed by the FCVAM model, coastal erosion is the one that both influences and is influenced by geomorphologic processes the most. The FCVAM model uses 6 parameters for physical characteristics and 5 parameters for anthropogenic activities in representing the mechanism of coastal erosion (Table 1).

\begin{tabular}{|l|l|l|}
\hline & Physical Parameters & Human Influence Parameters \\
\hline \multirow{4}{*}{ Coastal Erosion } & 1. Rate of Sea Level Rise & 1. Reduction of Sediment Supply \\
\cline { 2 - 3 } & 2. Geomorphology & 2. River Flow Regulation \\
\cline { 2 - 3 } & 3. Coastal Slope & 3. Engineered Frontage \\
\cline { 2 - 3 } & 4. Significant Wave Height & 4. Natural Protection Degradation \\
\cline { 2 - 3 } & 5. Sediment Budget & 5. Coastal Protection Structures \\
\cline { 2 - 3 } & 6. Tidal Range & \\
\hline
\end{tabular}

Table 1. Parameters of FCVAM model representing the coastal erosion mechanism (Ozyurt, 2010).

The physical parameters for erosion include and integrate the impact of climate change through sea level rise, geomorphology through landforms, and coastal processes through waves, the sediment budget and tidal range. Waves and tides are used to classify the shoreline as a high \low energy shoreline so as to determine whether or not coastal geomorphologic processes are governed by natural drivers. The sediment budget parameter - originating from the historical evolution of the shoreline - shows whether geomorphologic processes are dominant along the coastal area. The type of landforms points out the overall susceptibility of the shoreline to geomorphologic processes. All of the parameters mentioned are related to a long shore spatial scale.

The human influence parameters - also given in Table 1 - require assessments of their own which need to derive information from geomorphology studies as well. Due to activities outside the coastal zone, natural ecosystems (particularly within the catchments draining to the coast) have been fragmented and the downstream flow of water, sediment and nutrients has been disrupted (Nilsson et al. 2005). Land-use change - particularly deforestation - and hydrological modifications have had downstream impacts in addition to localised development on the coast. As stated by Jiongxhin (2004) erosion in the catchment has increased the river sediment load; for example, suspended loads in the Huanghe (Yellow) River have increased 2 to 10 times over the past 2000 years. In contrast, damming and channelisation have significantly reduced the supply of sediments to the coast on other rivers through retention of sediment in dams. Indeed, this latter effect will likely dominate the 21st century. On the other hand, land use change along the shoreline (long shore scale) also changed the amount of sediment supply available to coastal processes. Excavation of the coastal zone, sand mining and urbanisation contribute to the change in the sediment budget because of human use of the coast. Human activities controlling the flow rate of rivers also have a significant impact on the supply of sediment to coastal areas.

Two parameters (the reduction of sediment supply and river flow regulation) are inserted into the FCVAM model in order to reflect these mechanical processes and the spatial scales of these mechanisms. The reduction of sediment supply is defined as the ratio of 
present sediment supply to the region to the natural state sediment supply in Ozyurt (2007). This parameter covers the sediment trapped in dams or reservoirs at the upstream of the river, the excavation of the coastal zone, mining and changes in land use. It defines the sediment particle itself and the abundance of it through different mechanisms, including the control structures on rivers that trap sediment. On the other hand, the river flow regulation parameter shows the degree of impact of any regulative structure on rivers at the down drift in terms of flow rate by using the methodology of Nilsson et al. (2005) relating to the flow regulation index (Ozyurt, 2007). This parameter focuses on the modification of the flow rate and the change in sediment movement along the river. As is well-documented in the literature, unregulated rivers carry the most sediment, partly because sediment is not trapped behind dams and partly because of the flushing of the river channel during floods or else high flow rates. While control structures enable stable flow rates, this change decreases the amount of sediment carried to the coastal area by generating favourable conditions for the settling of sediment particles along river channels (Ozyurt, 2010). The reduction of the sediment supply and river flow regulation parameters dictate the spatial scale (that is, if there is a river within the coastal zone then the basin is automatically included in the assessment as well as the associated processes influencing the geomorphology such as sediment transport). River basin management authorities can provide the necessary information for both parameters and this automatically secures the integration of other stakeholders - especially the ones along the river basin - as well.

Many structures, such as groins, seawalls, breakwaters and revetments, occupy coastal areas for different purposes, including the control of erosion and land loss. However, these structures themselves initiate undesirable impacts on the sedimentary processes of the region or neighbouring regions. Structures parallel to the coast - such as seawalls cause the erosion of land in front of the structure and - in time - the whole of the land is lost if no other measure is put into practice. Although coastal protection structures may have a negative impact on adjacent shores, properly designed structures control the erosion and even initiate accretion within their region. Thus, coastal protection structures can decrease the vulnerability of the region when they work properly, achieving the intended results if adapted to sea level rise. If no adaptation measures are taken, these structures will lose their efficiency and, therefore, the vulnerability of the region will be increased.

Two parameters (engineered frontage and coastal protection structures) are included in the FCVAM so as to integrate the intervention of man-made structures on the coastal processes that alter coastal geomorphology. The engineered frontage parameter shows the percentage of the shoreline that the coastal structures occupies. This parameter includes all coastal structures (such as harbours, marinas, jetties and navigation channels) that do not have any purpose relating to the protection of the shoreline as well as coastal protection structures, which might cause adverse effects on adjacent shorelines. The coastal protection structures parameter, on the other hand, shows the percentage of shoreline that the coastal protection structures (such as groins and seawalls) occupy. As previously mentioned, coastal protection structures increase the resilience of the region if properly designed and adapted to sea level rise scenarios. 
Another effect of human activities along coastal areas is the change in the ecosystem that increases the resilience of the coastal area, such as dunes and wetlands. However, these systems are under threat of urbanisation and other anthropogenic pressures. The natural protection degradation parameter shows the status of the ecosystem (such as dunes and marshes and wetlands) which provides protection for the coast. If the system is healthy, then the resilience of the area to the impact of sea level rise is high. For example, dunes act as both sediment supply sources against erosion as well as a barrier to inundation. If there is sand extraction from these dunes, although the area may be naturally resilient human activity significantly decreases this resilience. This change in the ecosystem also affects such the mechanisms as sediment transport which in turn impacts the geomorphologic processes.

In view of the aims of this study, the wave statistics and the spatial scale available for the region control the temporal scale which is used by the FCVAM for assessing coastal erosion vulnerability. For the coastal erosion process, the wave climate is one of the basic governing forces. Although single extreme events such as storms contribute to significant shoreline changes of a short duration, the coastal area always tries to establish equilibrium in the longer term. It is important to underline that storm-based coastal erosion might be more critical at some locations rather than long-term balance. For these locations, high resolution spatial scale and numerical modelling should be applied. This vulnerability might be what governs the natural hazard aspect of ICZM in the short temporal scale. However, if the time scale of sea level rise is considered, longer trends gain in importance. This is the reason for inserting another parameter (the sediment budget parameter) that represents historical and present shoreline movements so as to assess the vulnerability of coastal areas to coastal erosion.

The assessment of vulnerability due to storm surges is another module of the FCVAM (Table 2). Storm surges also have an impact on geomorphologic processes. However, the FCVAM model evaluates the flooding of coastal areas due to storm surges. Nevertheless, the time scale of the assessment - in terms of flooding - can be controlled through the storm surge height parameter by determining the return period $(1,10,100,1000$ years).

Inundation, saltwater intrusion to groundwater resources and rivers are also included in the FCVAM, and geomorphology has influence on these processes as well (Table 2). Beach slope is the main parameter for the inundation mechanism, which is determined by the type of landform present at the coastal area. The properties of the soil layer and land use have an impact on the recharging of aquifers which, in turn, is included in the groundwater vulnerability assessment module. Also coastal geomorphologic processes significantly influence the geometry of the river mouth, which is represented by river depth in the river vulnerability assessment module. As can be seen, the parameters of the assessment are selected by analysing geomorphology studies for several time and spatial scales as well as other mechanisms. Thus, it would be appropriate to say that the upgrading of the assessment model is highly dependent on the advancement of geomorphology literature.

The next section will present examples of the application of the FCVAM model at different sites, focusing on the parameters directly related to geomorphology in addition to the concept of scale. 


\begin{tabular}{|c|c|c|}
\hline & Physical Parameters & Human Influence Parameters \\
\hline $\begin{array}{l}\text { Flooding due to Storm } \\
\text { Surges }\end{array}$ & $\begin{array}{l}\text { 1. Rate of Sea Level Rise } \\
\text { 2. Coastal Slope } \\
\text { 3. Storm Surge Height } \\
\text { 4. Tidal Range }\end{array}$ & $\begin{array}{l}\text { 1. Engineered Frontage } \\
\text { 2. Natural Protection Degradation } \\
\text { 3. Coastal Protection Structures }\end{array}$ \\
\hline Inundation & $\begin{array}{l}\text { 1. Rate of Sea Level Rise } \\
\text { 2. Coastal Slope } \\
\text { 3. Tidal Range } \\
\end{array}$ & $\begin{array}{l}\text { 1. Natural Protection Degradation } \\
\text { 2. Coastal Protection Structures }\end{array}$ \\
\hline $\begin{array}{l}\text { Salt Water Intrusion to } \\
\text { Groundwater Resources }\end{array}$ & $\begin{array}{l}\text { 1. Rate of Sea Level Rise } \\
\text { 2. Proximity to Coast } \\
\text { 3. Type of Aquifer } \\
\text { 4. Hydraulic Conductivity } \\
\text { 5. Depth to Groundwater } \\
\text { Level Above Sea }\end{array}$ & $\begin{array}{l}\text { 1. Groundwater Consumption } \\
\text { 2. Land Use Pattern }\end{array}$ \\
\hline $\begin{array}{l}\text { Salt Water Intrusion to } \\
\text { Rivers/Estuaries }\end{array}$ & $\begin{array}{l}\text { 1. Rate of Sea Level Rise } \\
\text { 2. Tidal Range } \\
\text { 3.Water Depth at } \\
\text { Downstream } \\
\text { 4. Discharge }\end{array}$ & $\begin{array}{l}\text { 1. River Flow Regulation } \\
\text { 2. Engineered Frontage } \\
\text { 3. Land Use Pattern }\end{array}$ \\
\hline
\end{tabular}

Table 2. Parameters of the FCVAM model representing other mechanisms included in the model (Ozyurt, 2010).

\section{FCVAM case studies: Viveiro, Spain, B'Buga, Malta and Silifke, Turkey}

The FCVAM methodology can be applied at different spatial resolutions, depending on the objective of the assessment. The model can compare coastal areas from the NUTS3 level to local administrative unit levels with higher spatial resolution scales, since the model can analyse all of the combinations of model parameters having a range of input values. The application of the model is possible at a very coarse resolution such that aggregated vulnerability scores for different administrative units are used to evaluate national assessments and regional planning. At a local scale, it uses GIS-based high resolution data; the model analyses different impacts and the governing processes for a specific area. However, when the model is integrated with GIS-based information, the spatial scale of the assessment depends on the detail of the available information for a particular site rather than the extent of the research area. Both levels of assessment and how the different geomorphologic processes and landforms influence the model will be illustrated with case studies.

Three case study sites are chosen at the LAU2 (local administrative unit) level which corresponds to towns $\backslash$ municipalities at different countries. The model is applied to coastal strips within administrative borders using information from the database built by Ozyurt (2010) and the published research on these locations. The studies are also used to verify and validate applicability of the FCVAM model to different coastal areas and how the results can be applied to regional planning. The sites chosen are the Viveiro in Lugo province of Spain (Northern Spain), the B'Buga municipality of Malta (Southeast of Malta) and the town of Silifke, Turkey (south Turkey). These sites represent different landform types as well as different levels of human intervention on the geomorphologic processes from the perspective of ICZM planning and coastal vulnerability to sea level rise. 


\subsection{Database}

The database build by Ozyurt (2010) covers most of the European coastlines from the Baltic Sea to the Atlantic Ocean and the Mediterranean Sea and include information on 79 major river basins and the aquifers of nine EU countries. This variety of coastal properties ensured the compilation of a thorough dataset enabling the application of the model to different coastal areas around the world. The database includes information on all the parameters of the FVCAM model presented in Table 1 and Table 2. Some of the databases used by Ozyurt (2010) form a part of other databases, which are either publicly or commercially available. However, all of the data collected and used by Ozyurt from these databases is available free for research. Some of the studies which were used to develop the database of Ozyurt (2010) were the EUROSION project, the DIVA project, the Digital Dataset of the European Groundwater Resources, the RivDIS dataset, the Waterbase dataset, the WWDII dataset and several national datasets. Details on the representation of different parameters within the developed database and the processes used to develop the GIS-based database are explained in Ozyurt (2010) in detail. The spatial resolution of the compiled dataset is not homogenous throughout European coasts (for some parameters, only information at a coarser resolution is available).

\subsection{Case study areas: Viveiro, Spain}

Viveiro (also known as Vivero) is a town and municipality in the province of Lugo, in the north-western Galician autonomous community of Spain. It has a residential population of over 16,000 (2010 figures), which triples in the summer months with visitors to the coastal region. Viveiro Ria is open to the north and is separated from the Barqueiro Ria by Coelleira Island (Fig. 3) on the lee side of Cape Estaca de Bares. The Landro River has developed an estuary in the inner part of the inlet. Its mouth complex used to present large sand spit, growing eastward from Covas headland. The Viveiro Ria is significantly affected by human occupation. The area includes the important fishing seaport of Celeiro in addition to extensive urbanisation and industrialisation. This occupation affects a large part of the marshland - most of which has been reclaimed - resulting in its current degraded state. Additionally, the highly modified Covas beach has developed between Punta Anchousa to the west and a dike to the east. The construction of the dike and the occupation of the dunes have resulted in a considerable erosion of sand. This loss has been compensated for with artificial regeneration of the beach. Research by Lorenzo et al. (2010) states that "the most significant changes on the beach and spit system have been (1) complete occupation of the dune area of the bar, (2) infilling of the former channel and of the Celeiro inlet, (3) construction of the seawalls of the Celeiro port, and (4) channelling of the Landro River outlet." On the other hand, the coastal strip of the administrative unit is dominated by rocky and medium cliffs, where the cliffs on the eastern side of the bay show signs of erosion. Small pocket beaches also exist along this indented coastal strip of the administrative borders of Viveiro.

\subsection{Case study areas: B'Buga, Malta}

The Maltese Islands have a collective shoreline of about $190 \mathrm{~km}$ and a surface area of 316 squares kilometres. Rough estimates indicate that only approximately $1.2 \%$ of the total land surface is $1 \mathrm{~m}$ or less above sea level. In fact, the islands' coastline is characterised by cliffs, clay slopes and boulder rocks (Fig. 4). 50\% of Malta's coasts and 74\% of Gozo's coastline 
have been defined as inaccessible, mainly due to physical features (Malta Structure Plan, 1990 as cited in Axiak, 1992). This leads to heavy pressures being exerted on the remaining lowlands for touristic, industrial and urban purposes. Sandy beaches constitute only $2 \%$ of the coastline. Nonetheless, these very restricted localities and the rest of the coastal lowlands support a number of unique and important habitats, such as saline marsh lands, sand dunes and gentle rocky slopes. Coastal erosion is one of the human-induced pressures, including urban settlement and coastal development, land-based pollution and quarrying activities on the coastal lowland (Axiak, 1992).

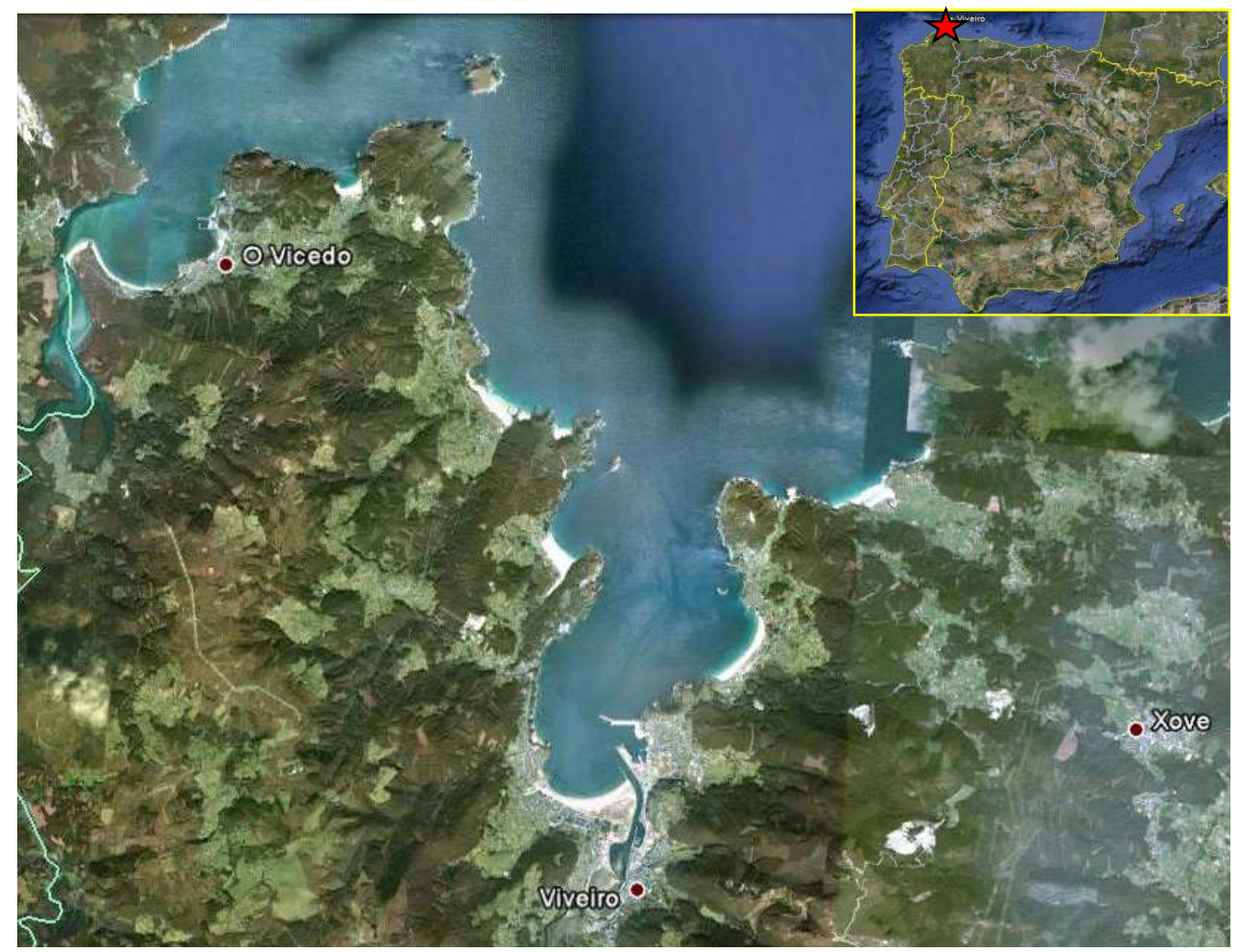

Fig. 3. Google Earth image of Viveiro, Spain

Birzebbuga is a fishing port and small resort on the western side of Marsaxlokk Bay (Fig. 4). Its population increased because of the workers employed at the nearby Malta Freeport and container terminal. Popular among Maltese holiday-makers, the location is known for its important archaeological sites and a sandy beach. However, the coastal strip is mainly dominated by rocky cliffs and the heavy coastal structures of the Malta Freeport and container terminal.

The water supply in Malta is of two types. First class water is treated to potable standards and used for tap water. Second class water is non-potable and used mostly in agriculture and by some industries. First class water is derived from groundwater and five Reverse Osmosis (RO) desalination plants. These RO plants currently account for most of the water 
production and were introduced because of the high salinity levels in the mean sea level aquifer (Birdi, 1997). Groundwater is extracted from two main water tables. Almost all of the groundwater supplies (95.1\%) are extracted from the mean sea level aquifer, a freshwater lens resting on denser seawater, and a small amount is obtained from the perched aquifer $(4.9 \%)$, resting on a Blue Clay aquiclude in the west of Malta. Large quantities of groundwater are also extracted by farmers, industries and the private owners of boreholes. Unsustainable extraction policies, particularly during the 1970 's, have meant that the water table is presently $40 \%$ over-exploited (Birdi, 1997).

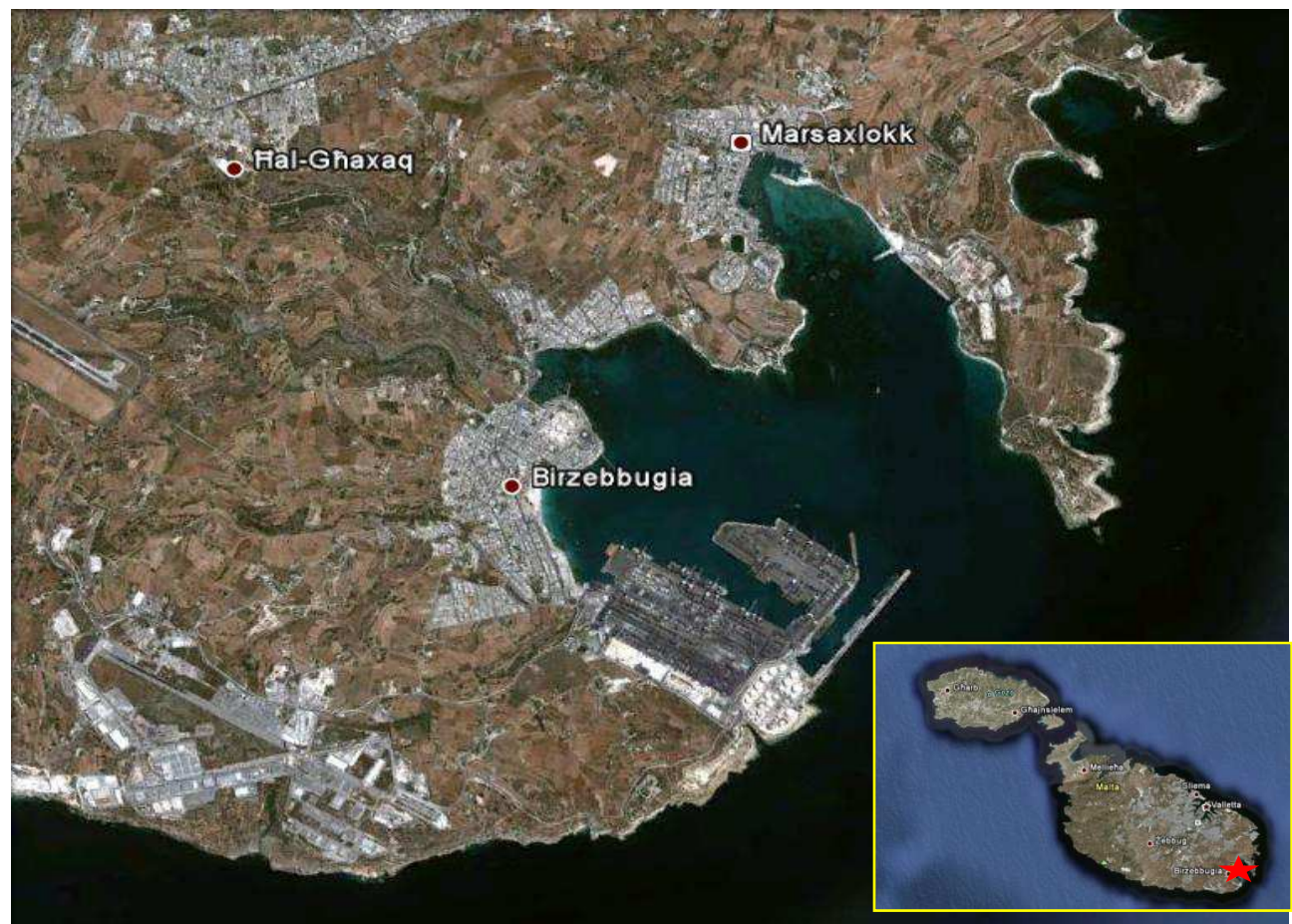

Fig. 4. Google Earth image of B’Buga, Malta

\subsection{Case study areas: Silifke, Turkey}

Most of the important economic activities take place on or near the coastal areas and especially on deltas. While low elevations increase physical vulnerability, the high level of socio-economic activity exacerbates the vulnerability of these areas. One of these regions is the Goksu delta, which is located on the south of Silifke, Mersin, where the Goksu river with a $10000-\mathrm{km} 2$ catchment area - reaches the Mediterranean Sea. The coastal area of Silifke is dominated by the formation of the Goksu delta. The delta - surrounded by the Taurus Mountains to the north and northeast - is split into two by the Goksu river. There are two shallow lakes: Paradeniz and Akgöl, to the east and west respectively (Fig. 5). 
The Goksu delta is known for the important biodiversity of its flora and fauna, which led to the Specially Protected Area status that it claimed in 1991. In 1994, the wetlands of the delta were included in the RAMSAR list (List of Wetlands of International Importance). The richness of the fauna of the Goksu delta is influenced by its geographical location as well as its ecology. The presence of the major sea turtles (Caretta caretta) nesting beaches on the Mediterranean and its importance in terms of ornithology make the delta one of the most diverse and valuable ecosystems in the region. In addition to its important ecological properties, the delta has become an important agricultural area, leading to rapid socioeconomic development since the implementation of irrigation network in 1968. The use of the river as a freshwater resource as well as the aquifers of the region has increased substantially after the 1980s when rice production started to dominate the agricultural landscape. High demand for freshwater - especially for groundwater - has led to sharp decreases in the water tables and the intrusion of sea water into some of the coastal aquifers. Across the region there are 5 municipalities and 7 villages, and the population is increasing with a rate above the average rate of the country. All of the economical, physical and ecological properties of the Göksu delta demonstrate the importance of this low-lying land, which has an average elevation of $2 \mathrm{~m}$ above sea level (Ozyurt \& Ergin, 2009).

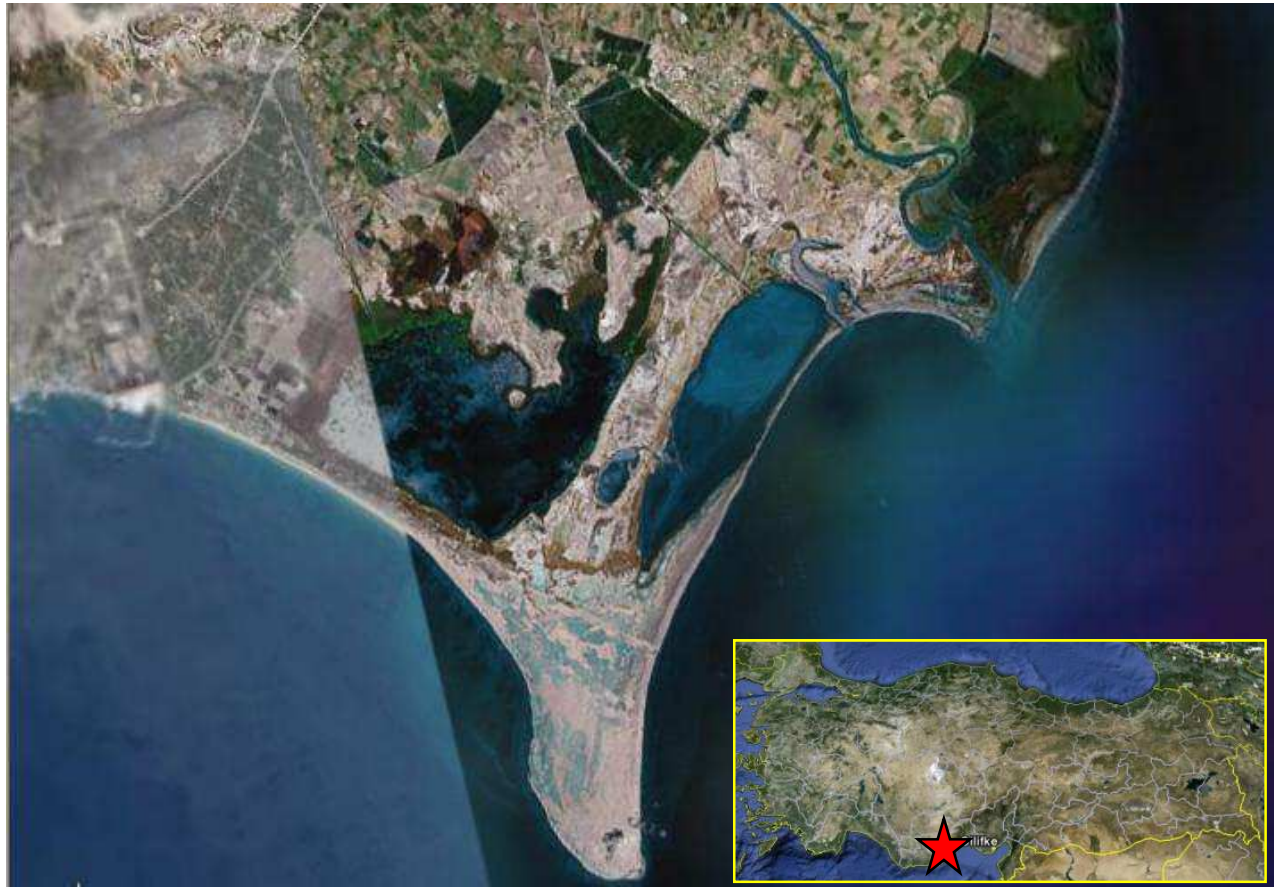

Fig. 5. Google Earth image of Goksu Delta, Silifke, Turkey

\section{Results of the FCVAM Analysis}

The FCVAM analysis is performed for the three case study areas by using the inputs collected from database of Ozyurt (2010) and published research papers on the specific sites 
(Axiak, 1992; Birdi, 1997; Lorenzo et al, 2010; Ozyurt and Ergin, 2009). Table 3 presents the input values for the three study areas. Some of the data presented in Table 3 needs preprocessing steps. These pre-processing steps are explained in detail in Ozyurt (2010).

\begin{tabular}{|c|c|c|c|}
\hline Physical Inference Parameters & Viveiro & B’Buga & Goksu \\
\hline Rate of Sea Level Rise (mm/year) & 2.5 & 1 & 2 \\
\hline Geomorphology & Medium cliffs & Rocky cliffs & Delta \\
\hline Beach Slope (\%) & 2.6 & 3 & 1 \\
\hline Significant Wave Height (m) & 2.96 & 1.04 & 3 \\
\hline Sediment Budget (\%) & -17 & -3 & -50 \\
\hline Storm Surge Height (m) & 6 & 3 & 4 \\
\hline Tidal Range (m) & 2.75 & 0.1 & 0.3 \\
\hline Proximity to Coast of aquifer $(\mathrm{km})$ & NA & 0.4 & 0.4 \\
\hline Type of Aquifer & NA & Unconfined & Unconfined \\
\hline Hydraulic Conductivity of aquifer & NA & 0.001 & 0.000016 \\
\hline Depth to Groundwater Level (m) & NA & 0 & 2 \\
\hline River Discharge (m3/s) & 7.5 & NA & 90 \\
\hline River Water Depth (m) & 1 & NA & 1 \\
\hline \multicolumn{4}{|l|}{ Human Inference Parameters } \\
\hline Reduction of Sediment Supply (\%) & 30 & 0 & 60 \\
\hline River Flow Regulation & Not affected & NA & $\begin{array}{c}\text { Moderately } \\
\text { affected }\end{array}$ \\
\hline Engineered Frontage(\%) & 27 & 10 & 5 \\
\hline Groundwater Stress(\%) & NA & 140 & 80 \\
\hline Land Use & Unclassified & $\begin{array}{l}\text { Settlement } \backslash \\
\text { Industry }\end{array}$ & Agriculture \\
\hline Natural Protection Degradation (\%) & 17 & NA & 60 \\
\hline Coastal Protection Structures (\%) & 9.3 & 10 & 3 \\
\hline
\end{tabular}

Table 3. Input data used for the FCVAM Analysis. 
The results of 3 case studies are given in Table 4 . These values should be discussed using a scale of 1 to 5 which the FCVAM model also translates into levels of vulnerability, such as very low, low, moderate, high and very high (Ozyurt, 2010).

The coastal vulnerability assessment of the three different case study sites shows that Viveiro and B'Buga show moderate vulnerability to the impact of sea level rise and that the Goksu Delta (Silifke) shows a high vulnerability according to the aggregated vulnerability scores. The results are compatible with the literature on the impact of sea level rise on coastal landforms presented in the IPCC Assessment Reports (2007). The IPCC Assessment Reports (2007) generalise the vulnerability of coastal areas to sea level rise in terms of coastal landforms; cliff and indented coastlines inherit moderate vulnerability while deltas and low lying lands show high vulnerability, particularly to the impact of sea level rise.

\begin{tabular}{|l|l|l|l|l|l|l|}
\hline & \multicolumn{5}{|l|}{ Regions } \\
\hline & \multicolumn{7}{|l|}{ Viveiro } & \multicolumn{2}{l|}{ B'Buga } & \multicolumn{3}{l|}{ Goksu } \\
\hline Impacts & 3.00 & Moderate & 2.14 & Low & 4.00 & High \\
\hline Inundation & 3.20 & Moderate & 3.00 & Moderate & 4.05 & High \\
\hline Storm Surge & 4.00 & High & 3.00 & Moderate & 4.00 & High \\
\hline Groundwater & NA & NA & 4.01 & High & 3.83 & High \\
\hline River & 2.00 & Low & NA & NA & 2.88 & Moderate \\
\hline VULNERABILITY INDEX & 3.05 & Moderate & 3.09 & Moderate & 3.71 & High \\
\hline
\end{tabular}

Table 4. Results of the fuzzy vulnerability assessment model for the three case study sites.

The first case study area is the Viveiro region, where medium cliffs and indented coastal strips with pocket beaches dominate the geomorphology. Since the assessment is performed at the LAU2 level, the information on the geomorphology of the region has been determined using the most dominant characteristic, namely medium cliffs and indented coasts. This geomorphology indicates the low vulnerability of the coastal area as a region. Moreover, the aggregated vulnerability score shows that the region is moderately vulnerable to the impact of sea level rise. Moderate vulnerability is assigned to coastal erosion and inundation for the region where the high resilience of the geomorphologic characteristics of the coastal strip to withstand the high energy of such driving forces as tides and waves. The high vulnerability of the region to storm surges (documented by measurements (Lorenzo et al. 2007)) highlights the dominance of the driving forces of geomorphologic processes. Impact vulnerabilities are governed by the physical characteristics of the region and for processes along shorelines, and human intervention adds to the vulnerability to a moderate level. The assessment - using aggregated information for a large spatial area - is not able to highlight 
the variance of vulnerability across the region since the possible higher vulnerability of the pocket beaches were not reflected in the results. However, studies on the dynamics on the main beach (Cove beach) of the area shows that the beach is mostly stable because of annual artificial nourishment. Nonetheless, the moderate vulnerability score for coastal erosion is sufficient to explain the vulnerability of the coastal zone of the region, although the application of low resolution data misses the variance in vulnerability at higher spatial resolution. Additionally, due to the variability of the vulnerability of pocket beaches an assessment using higher resolution spatial data should be applied. The aggregated vulnerability score shows moderate vulnerability while the high vulnerability score for storm surge impact underlines the necessity for short term spatial planning, as is the case in Goksu, Turkey. Although the cliff geomorphology is resistant to flooding, medium cliffs are prone to erosion and the high energy driving force can initiate cliff erosion as well as short term coastal erosion along pocket beaches. The possibility of cliff erosion along the most exposed coast strip is also documented in Lorenzo et al. (2007).

The assessment of the B'Buga region in Malta demonstrates a moderate score of aggregated vulnerability, very similar to that of Viveiro, Spain. Although the scores are close, the ranking of the impact vulnerability scores are different, showing that the aggregated vulnerability score by itself might mask the importance of individual impacts. The same discussion holds true for the different results of the assessment using different spatial resolutions, as with the case of Viveiro. The dominant geomorphology of the B'Buga region is its rocky cliffs, although inside the bay there are small beaches protected by a huge port infrastructure that has recently been constructed. The resilience of the geomorphology combined with milder forces (waves and tides) for geomorphologic processes determines the low to moderate vulnerability in terms of the impacts along the shoreline. Coastal erosion scores signal the low vulnerability of the region, which is also protected from the driving forces via coastal structures. Storm surge and inundation impacts show moderate to low vulnerability. These scores can be attributed to the natural resilience of the coastal strip and significant human intervention which act as protection measures. On the contrary, the vulnerability of groundwater resources for the whole island shows high vulnerability. The over-exploitation of the available resources due to land use and urbanisation, as well as the low resilience of the aquifer, generates the high vulnerability score for this region.

In terms of ICZM planning, the scores show that the most vulnerable resource is groundwater. Although the natural vulnerability of the aquifer is moderate, the high impact of human influence on the vulnerability highlights future problems and urges the preparation of policy actions both for the short term and the long term. The installation of RO plants on the island is one of the actions that can be considered in line with the results of the assessment. However, more actions are needed in the long term. Similar to the case of Viveiro, the assessment of aggregated values for a long coastal strip masks the vulnerabilities of small beaches within the region which might have higher scores. Thus, a similar type of assessment is required using detailed data, the results of which might point out a more definite framework for the future application of ICZM plans.

The vulnerability scores for Goksu point out that the region is highly vulnerable to geomorphology dependent coastal processes such as erosion, flooding and inundation. 
Figure 7 shows the influence graphs of Goksu, Turkey in addition to the impact and vulnerability scores. These graphs are important for local decision-making processes, while the comparison of different sites according to the overall vulnerability scores enables planning for the regional to national management of coastal areas. The histogram shows that although human influence on the geomorphologic processes is significant (scores for human influence parameters indicate moderate vulnerability), it is the physical properties of the region that governs the vulnerability. Many of the physical parameters are part of the geomorphologic mechanisms, either as driving forces or as affected attributes, and the scores of these parameters for the Goksu region signal a high vulnerability as reflected by the aggregated vulnerability of the whole region. On the other hand, the vulnerability of groundwater resources is human influence-driven, although the physical characteristics of the aquifers indicate the resilience to sea level rise. It is the establishment of the level of influence of different processes along the coastal area that enables us to generate a framework for the Goksu region in terms of ICZM planning. In terms of high vulnerability impacts where geomorphologic processes govern the dynamics, the understanding of local geomorphology dynamics and the impact of human activities over the long term represents the key areas that ICZM practice should be based on. The high score of flooding due to storm surges indicates that a short term temporal scale should be included in the modelling, underlining the necessity for numerical model studies for this site. Since the physical properties of the region dominate the vulnerability, management options need to be more structure-based, at least in terms of soft protection options such as nourishment or dune planning (Ozyurt \& Ergin, 2010).

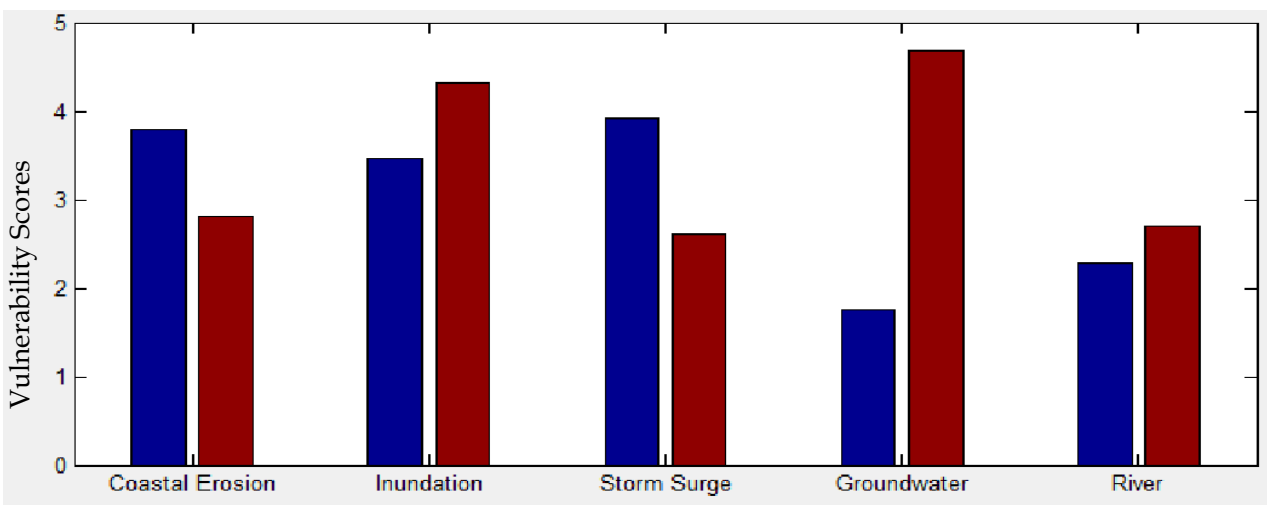

Fig. 7. Influence Histogram for Goksu (red columns indicate the human inference system, blue columns indicate the physical inference system). 
As was previously mentioned, ICZM aims to manage all the resources available on the coastal area, including fresh water resources. For Goksu, both river and groundwater resources are assessed in terms of vulnerability to sea water intrusion. Although the river shows moderate vulnerability - due to higher scores of human influence parameters - the possibility of higher vulnerability can be expected in the long term. This result indicates that ICZM should consider adjusting the human activities along the spatial extent of the region, including the river basin management. On the other hand, groundwater resources show high resilience if not over exploited. However - as is shown by the histogram - the human parameters show the highest vulnerability score. Thus ICZM plans must consider policydriven options that include both short term solutions as well as long term applications for the sustainability of aquifers.

\section{Conclusion}

For the sustainability of coastal areas, integrated coastal zone management has become the leading concept which requires the integration of many concepts studied by different disciplines, such as geology, geomorphology, coastal and marine sciences, sociology, etc. The study of the geomorphology of coastal areas - focusing on landforms and the processes that shape them - is one of the core disciplines required for successful and efficient ICZM practice. The information generated by geomorphologic studies acts as a foundation for other studies included in ICZM plans - such as vulnerability assessments by determining the scale of the assessments, the processes to be included and options to be assessed.

The results of the case study locations assessed by the FCVAM are used to discuss the role of geomorphology in the vulnerability of coastal areas. Additionally, the integration of spatial and temporal scales within the model, considering the different scales of geomorphology and the ICZM, are presented through these examples. The assessment methodology uses the concepts and theories of geomorphology (landform processes, drivers and factors) such that different processes (such as waves, tides) acting on the geomorphology are integrated and evaluated by using governing parameters which are not limited to spatial or temporal scales. Geomorphology in terms of coastal land forms is directly included in the FCVAM model. In addition, the site-specific application of the model is suggested to be performed by preparing the model database, determining coastal strips with respect to their geomorphological properties and focusing on landforms. The processes related to specific landforms are the main properties that also define the vulnerability of the coastal zone, and the relationships between these processes and landforms are the structural backbone of FCVAM model. The selection processes of the parameters to be included in site-specific assessments using the FCVAM model are dependent on the study of geomorphology and its theories of specific landforms, as presented in the discussion on the model's parameters.

The fuzzy coastal vulnerability assessment methodology (Ozyurt, 2010) was used to assess different coastal areas showing various physical and geomorphological properties as well as different levels of socio-economic development patterns. The regional application of the FCVAM is presented by comparing three different locations (Viveiro, Spain; B'Buga, Malta and Silifke, Turkey) at the LAU2 level using coarse resolution data. The data used for the 
regional application of the model needs to represent the properties of the region. However, the coarse resolution of the data used for the FCVAM's application is efficient enough to analyse the vulnerability of these regions and compare them to each other so as to determine regional policies on coastal zone management. On the other hand, the vulnerability scores of individual impacts and the histograms give the most information on the level of vulnerability and the influence of geomorphologic processes of a region. The degree of human intervention on these processes is also presented in the histogram provided in Figure 7. Both the scores and histogram shown in Figure 7 enable policy makers to develop ICZM plans in the long term by creating a framework of possible actions. However, in order to generate efficient histograms, the model needs to be run at a local level with high resolution data or for regions where geomorphology is homogeneous for the study area. Such a case is represented by the study on Goksu, Turkey. The site where geomorphology is dominated by delta formation enables the FCVAM model to analyse relationships between physical and human influence parameters as well as indicating possible adaptation measures for different impacts.

One of the recurring themes is the masking of variability of vulnerability along a shoreline as a result of the application of the model to a coarser spatial resolution. The use of aggregated data to define some of the parameters - especially parameters related to geomorphology - can mask higher or lower vulnerability zones, such as was the case with the pocket beaches in Viveiro. In that case, although the variability is lost in terms of geomorphologic processes, the impact vulnerability scores still help to understand the variability of vulnerability across different types of processes.

Finally - as was previously highlighted - geomorphologic processes are both derived and driven by many mechanisms, and a combination of these mechanisms is the goal of efficient ICZM practice. To achieve this objective, the models of different natures and complexities try to overcome many of the problems faced by geomorphology research and ICZM practice. The FCVAM model and case studies presented represents one of these models and tries to achieve the integration of different processes efficiently. In the end, the problems related to many of the concepts above mentioned are what drive many researchers from many disciplines to continue searching. As Malcolm Muggeridge (What I Believe) has put it in words "IF I COULD UNDERSTAND A GRAIN OF SAND, I SHOULD UNDERSTAND EVERYTHING."

\section{Acknowledgment}

The development of the Fuzzy Coastal Vulnerability Assessment Model is partly supported by research from "Kıyılarda İklim Değişikliğine Karşı Kumlanma Modeli Destekli Kırılganlık Analizi Projesi - KIDEKA" (Coastal vulnerability assessment model coupled with sediment transport model) Project supported by the TUBITAK Research Grant No: 108M589.

\section{References}

Axiak, V. (1992) Implications of expected climatic changes on the island of Malta: identification and assessment of possible climatic change on marine and freshwater ecosystems. UNEP Report. 
Beatley, T., Brower, D.J. and Schwab A.K. (2002). “An Introduction to Coastal Zone Management". Second Edition. Island Press.

Bird, E. C. F. (2008). “Coastal geomorphology : an introduction" Second Edition. Wiley.

Birdi, N. (1997). Water scarcity in Malta. GeoJournal, 41.2: pp. 181-191.

Davis, Richard A. (1993) “The Evolving Coast." Scientific American Library. Printed in USA. p. 231.

French, J.R. and Burningham, H. (2009). Coastal geomorphology: trends and challenges. Progress in Physical Geography, Vol. 33 No. 1 pp. 117-129.

IPCC. (2007). "Intergovernmental Panel on Climate Change (IPCC) Fourth Assessment Report: Climate Change 2007 Impacts, Adaptation and Vulnerability." M.L. Parry, O.F. Canziani, J.P. Palutikof, P. J. v. d. Linden, and C. E. Hanson, eds., IPCC, Cambridge, United Kingdom and New York, NY, USA.

Jiongxin, X., 2004. A study of anthropogenic seasonal rivers in China. Catena, Vol. 55 pp. 1732.

Klein, R. J. T., \& Nicholls, R. J. (1999). Assessment of coastal vulnerability to climate change. Ambio, 28(2), pp. 182-187.

Lorenzo F., Alonso A., Pagés J. L. (2007) Erosion and Accretion of Beach and Spit Systems in Northwest Spain: A Response to Human Activity. Journal of Coastal Research, Vol. 23, No. 4 pp. 834-845.

McFadden, L., Nicholls, R. J. and Penning-Rowsell E. (Eds.). (2007). “Managing Coastal Vulnerability". Elsevier.

Nilsson, C., Reidy, C. A., Dynesius, M., and Revenga, C. (2005). "Fragmentation and Flow Regulation of the World's Large River Systems." Science, (308), p. 405.

Ozyurt, G. (2007). "Vulnerability of Coastal Areas to Sea Level Rise: Case Study on Goksu Delta," Master's Thesis. Middle East Technical University, Ankara.

Ozyurt,G. and Ergin, A.(2009). "Application of Sea Level Rise Vulnerability Assessment Model to Selected Coastal Areas of Turkey". Journal of Coastal Research, Special Edition 56, pp. 248-251.

Ozyurt, G., and Ergin, A. (2010). "Improving Coastal Vulnerability Assessments to Sea Level Rise: A New Indicator Based Methodology for Decision Makers." Journal of Coastal Research, 26(2), pp. 265-273.

Ozyurt,G. (2010) “Fuzzy Coastal Vulnerability Assessment to Sea Level Rise" PhD. Thesis. Middle East Technical University, Ankara.

Ospina-Alvarez, N., Prego R., Alvarez I., deCastro M., Alvarez-Ossorio M.T., Pazos Y., Campos M.J., Bernardez P., Garcia-Soto C., Gomez-Gesteira M., Varela M. (2010) Oceanographical patterns during a summer upwelling-downwelling event in the Northern Galician Rias: Comparison with the whole Ria system (NW of Iberian Peninsula) Continental Shelf Research, Vol.30 pp. 1362-1372.

Rotmans, J. and Rothman D. S. (2003) "Scaling in Integrated Assessment". Swets \& Zeitlinger.

Sanders M. H and Clark P. D. (Eds.) (2010) “Geomorphology: Processes, Taxonomy and Applications". Nova.

Schwartz, M. L. (Eds.) (2005) “Encyclopedia of Coastal Science". Springer.

US Army Corps of Engineers. (2003). "Coastal Engineering Manual." Washington, DC. 
Woodroffe, C.D. (2002) “Coasts: form, process and evolution”. Printed in UK, University Press, Cambridge. 


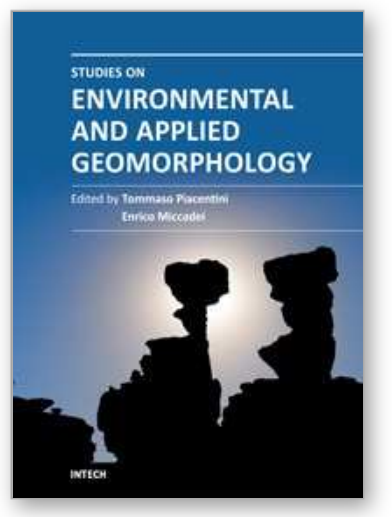

\author{
Studies on Environmental and Applied Geomorphology \\ Edited by Dr. Tommaso Piacentini
}

ISBN 978-953-51-0361-5

Hard cover, 294 pages

Publisher InTech

Published online 21, March, 2012

Published in print edition March, 2012

This book includes several geomorphological studies up-to-date, incorporating different disciplines and methodologies, always focused on methods, tools and general issues of environmental and applied geomorphology. In designing the book the integration of multiple methodological fields (geomorphological mapping, remote sensing, meteorological and climate analysis, vegetation and biogeomorphological investigations, geographic information systems GIS, land management methods), study areas, countries and continents (Europe, America, Asia, Africa) are considered.

\title{
How to reference
}

In order to correctly reference this scholarly work, feel free to copy and paste the following:

Gülizar Özyurt and Ayşen Ergin (2012). Spatial and Time Balancing Act: Coastal Geomorphology in View of Integrated Coastal Zone Management (ICZM), Studies on Environmental and Applied Geomorphology, Dr. Tommaso Piacentini (Ed.), ISBN: 978-953-51-0361-5, InTech, Available from:

http://www.intechopen.com/books/studies-on-environmental-and-applied-geomorphology/spatial-and-timebalancing-act-coastal-geomorphology-in-view-of-integrated-coastal-zone-management-i

\section{INTECH}

open science | open minds

\section{InTech Europe}

University Campus STeP Ri

Slavka Krautzeka 83/A

51000 Rijeka, Croatia

Phone: +385 (51) 770447

Fax: +385 (51) 686166

www.intechopen.com

\section{InTech China}

Unit 405, Office Block, Hotel Equatorial Shanghai

No.65, Yan An Road (West), Shanghai, 200040, China

中国上海市延安西路65号上海国际贵都大饭店办公楼405单元

Phone: +86-21-62489820

Fax: +86-21-62489821 
(C) 2012 The Author(s). Licensee IntechOpen. This is an open access article distributed under the terms of the Creative Commons Attribution 3.0 License, which permits unrestricted use, distribution, and reproduction in any medium, provided the original work is properly cited. 